\title{
The risks of sarcopenia, falls and fractures in patients with type 2 diabetes mellitus
}

Citation for published version (APA):

Sarodnik, C., Bours, S. P. G., Schaper, N. C., van den Bergh, J. P., \& van Geel, T. A. C. M. (2018). The risks of sarcopenia, falls and fractures in patients with type 2 diabetes mellitus. Maturitas, 109, 70-77. https://doi.org/10.1016/j.maturitas.2017.12.011

Document status and date:

Published: 01/03/2018

DOI:

10.1016/j.maturitas.2017.12.011

Document Version:

Publisher's PDF, also known as Version of record

Document license:

Taverne

Please check the document version of this publication:

- A submitted manuscript is the version of the article upon submission and before peer-review. There can be important differences between the submitted version and the official published version of record.

People interested in the research are advised to contact the author for the final version of the publication, or visit the DOI to the publisher's website.

- The final author version and the galley proof are versions of the publication after peer review.

- The final published version features the final layout of the paper including the volume, issue and page numbers.

Link to publication

\footnotetext{
General rights rights.

- You may freely distribute the URL identifying the publication in the public portal. please follow below link for the End User Agreement:

www.umlib.nl/taverne-license

Take down policy

If you believe that this document breaches copyright please contact us at:

repository@maastrichtuniversity.nl

providing details and we will investigate your claim.
}

Copyright and moral rights for the publications made accessible in the public portal are retained by the authors and/or other copyright owners and it is a condition of accessing publications that users recognise and abide by the legal requirements associated with these

- Users may download and print one copy of any publication from the public portal for the purpose of private study or research.

- You may not further distribute the material or use it for any profit-making activity or commercial gain

If the publication is distributed under the terms of Article $25 \mathrm{fa}$ of the Dutch Copyright Act, indicated by the "Taverne" license above, 


\title{
The risks of sarcopenia, falls and fractures in patients with type 2 diabetes mellitus
}

\author{
C. Sarodnik ${ }^{\mathrm{a}}$, S.P.G. Bours ${ }^{\mathrm{b}, \mathrm{c}}$, N.C. Schaper ${ }^{\mathrm{a}, \mathrm{d}}$, J.P. van den Bergh ${ }^{\mathrm{a}, \mathrm{b}, \mathrm{e}, \mathrm{f}}$, T.A.C.M. van Geel ${ }^{\mathrm{g}, *}$ \\ a NUTRIM Research School, Maastricht University, Maastricht, The Netherlands \\ b Department of Internal Medicine, Subdivision Rheumatology, Maastricht University Medical Centre, Maastricht, The Netherlands \\ c CAPHRI Research School, Maastricht University, Maastricht, The Netherlands \\ d Department of Internal Medicine, Subdivision Endocrinology, Maastricht University Medical Centre, Maastricht, The Netherlands \\ e Department of Internal Medicine, VieCuri Medical Center, Venlo, The Netherlands \\ ${ }^{\mathrm{f}}$ University Hasselt, Biomedical Research Institute, Hasselt, Belgium \\ ${ }^{\mathrm{g}}$ Maastricht University, CAPHRI Research School, Department of Family Medicine, Maastricht University, Maastricht, The Netherlands
}

\section{A R T I C L E I N F O}

\section{Keywords:}

Type 2 diabetes mellitus

Fracture risk

Sarcopenia

Falls

Bone quality

\begin{abstract}
A B S T R A C T
Fracture risk in patients with type 2 diabetes mellitus (T2DM) is increased, and the mechanism is multifactorial. Recent research on T2DM-induced bone fragility shows that bone mineral density (BMD) is often normal or even slightly elevated. However, bone turnover may be decreased and bone material and microstructural properties are altered, especially when microvascular complications are present. Besides bone fragility, extra-skeletal factors leading to an increased propensity to experience falls may also contribute to the increased fracture risk in T2DM, such as peripheral neuropathy, retinopathy and diabetes medication (e.g. insulin use). One of the probable additional contributing factors to the increased fall and fracture risks in T2DM is sarcopenia, the agerelated decline in skeletal muscle mass, quality and function. Although the association between sarcopenia, fall risk, and fracture risk has been studied in the general population, few studies have examined the association between T2DM and muscle tissue and the risks of falls and fractures. This narrative review provides an overview of the literature regarding the multifactorial mechanisms leading to increased fracture risk in patients with T2DM, with a focus on sarcopenia and falls.
\end{abstract}

\section{Introduction}

Type 2 diabetes mellitus (T2DM) is an increasing global health problem. In 2011, T2DM was diagnosed in 285 million people worldwide and it is expected that the global prevalence of T2DM will rise to 592 million by 2035 [1,2]. The prevalence of DM2 differs among gender but increases with age in both men and women. In men the prevalence of DM2 peaks at about 65 years $(\approx 18 \%)$ [3]. In women the prevalence of T2DM peaks at 75 years $(\approx 18 \%)$ [3]. In women, the decline of oestrogens during menopause [4] is associated with an increase of fat mass, especially abdominal fat, leading to visceral adiposity [5]. This has a negative effect on insulin sensitivity [6,7] resulting in an increased prevalence of diabetes in postmenopausal compared to premenopausal women $[8,9]$. In addition, the prevalence of T2DM in obese women increases even more after menopause compared to obese men at the same age, while before menopause obese men have a higher prevalence of T2DM [3].

T2DM is a chronic inflammatory disease characterized by insulin resistance and impaired glucose metabolism, and complications such as neuropathy and retinopathy $[10,11]$. Studies showed that patients with T2DM have a significant higher vertebral (relative risk ratio of 1.6) and non-vertebral fracture risk (relative risk ratio 1.7) compared with healthy controls [12-14]. In contrast, a recent study reported that in well-regulated patients with $\mathrm{T} 2 \mathrm{DM}$ with a relatively short disease duration, fracture risk was not increased [15].

Some national societies of osteoporosis recommend to use the FRAX tool for the evaluation of fracture risk [16-18]. However, it is reported that fracture risk in patients with T2DM is underestimated by FRAX $[19,20]$.

The underlying mechanisms related to fracture risk in T2DM are not yet clearly understood [21,22]. Bone properties may probably be affected in many patients with T2DM [23-26], although bone mineral

Abbreviations: T2DM, type 2 diabetes mellitus; BMD, bone mineral density; HR-pQCT, high resolution peripheral quantitative computed tomography; DXA, dual-energy X-ray absorptiometry; AGEs, advanced glycated end-products; ALM, appendicular lean mass; ROS, reactive oxidative species; SMI, skeletal muscle index

* Corresponding author at: PO BOX 616, 6200 MD Maastricht, The Netherlands.

E-mail address: tineke.vangeel@maastrichtuniversity.nl (T.A.C.M. van Geel). 
density (BMD) is often reported to be normal to elevated [10,27]. The effects of T2DM on bone micro-structural and bone material properties might result in an increased bone fragility [28].

Muscle strength and function are reported to be decreased in patients with T2DM compared to healthy controls [29,30]. Sarcopenia, the age-related decline in skeletal muscle mass, quality and function, is associated with T2DM [31-34]. In the general population, sarcopenia is a risk factor for falls and fractures [35,36]. However, the association between sarcopenia, fall and fracture risk in patients with T2DM is less clear. This narrative review provides an overview of the literature regarding fracture risk in patients with T2DM, with a focus on sarcopenia and falls.

\section{Methods}

In the search strategy, the following key terms were combined in PubMed: Diabetes Mellitus type 2, falls, fracture risk and sarcopenia, using different combinations. For type 2 diabetes mellitus the following medical subject headings (MeSH) and text terms were used: Diabetes Mellitus, Type 2; Diabetes Mellitus, Type 2 [Mesh]; diabetes type 2; DM2; diabetes; T2D. The following MeSH and text terms were used for falls: accidental falls [MeSH Terms]; accidental falls; falls. For fracture risk the following MeSH terms and text terms were used: Prediction of fracture risk; osteoporotic fractures; spontaneous fractures; Fracture risk; Fractures, Spontaneous [Mesh]; Osteoporotic Fractures [Mesh]. Lastly, the following MeSH and text terms were used for sarcopenia: Sarcopenia; Sarcopenia [Mesh]; sarcopenias.

\section{Bone fragility in T2DM}

In clinical practice, BMD as measured by Dual-energy X-ray absorptiometry (DXA) is used as a predictor of fracture risk and diagnosis of osteoporosis, defined as a T-score of $\leq-2.5$ [37].

Regardless of femoral neck BMD T-score and age, fracture risk was reported to be increased in patients with compared to those without T2DM [12-14,38]. Despite this finding, age adjusted hazard ratios (HRs) per SD decrease in BMD predicted hip fracture and non-spine fracture equally well in patients with and without T2DM [39]. Since BMD is overestimated in overweight or obese persons and many T2DM patients are obese $(55,7 \%)$, BMD may be overestimated in single measurements, while the change of BMD over time is not different in patients with compared to those without T2DM [26,40-42].

In some European countries, national guidelines recommend to use the FRAX tool for the evaluation of fracture risk [16-18]. The FRAX risk calculation is based on clinical risk factors for fractures (e.g. sex, age, BMI, rheumatoid arthritis, smoking, alcohol abuse previous fragility fractures, parental history of hip fractures, secondary osteoporosis, prolonged corticosteroid therapy) and the calculation can be performed with or without T-score of the femoral neck [43]. It was reported that patients with T2DM had mean FRAX scores lower than control subjects (probability of major osteoporotic fracture and hip fracture respectively $6,35 \%$ and $2,17 \%$ in T2DM compared to $7,75 \%$ and $2,91 \%$ ), despite a higher frequency of previous fractures $(29.88 \%$ in T2DM versus $20.46 \%$ in controls) [20]. In line with this, another study reported that for any given FRAX score the fracture risk in patients with T2DM was higher compared to controls [19], leading to the conclusion that diabetes confers an increased risk of fracture that is independent of FRAX derived with BMD. Therefore, FRAX may be not suitable to predict fracture risk in adults with T2DM. Bone strength and quality are determined by micro- and macro-structural properties and bone material properties, both influenced by bone turnover. While micro-architectural cortical and trabecular parameters are not reflected by BMD measurements, high resolution peripheral quantitative computed tomography (HR-pQCT) provides these micro-architectural parameters and in addition bone strength and stiffness can be estimated [44-46].

Micro-structural and material properties may be affected in patients with T2DM compared to healthy controls [28,47], although results of different studies are not uniform [28,48-50]. The estimated bone strength assessed at the distal radius by HR-pQCT was reported to be decreased in patients with T2DM [50]. Literature about cortical porosity in T2DM is inconsistent. In some studies, cortical porosity was higher in patients with T2DM at the radius compared to healthy controls [50,51] and higher in individuals with T2DM who sustained a fragility fracture compared to those without a fragility fracture $(+58,1 \%)$ [52]. However, another study observed no differences in cortical porosity at the distal radius and tibia in patients with T2DM compared to healthy controls [49]. Only one paper addressed a $10 \%$ higher trabecular density in patients with T2DM compared to controls [50].

Bone material properties are also reported to be affected in T2DM [23]. Chronic hyperglycaemia in combination with oxidative stress leads to an increase of Advanced Glycation End-products(AGEs) [53]. The accumulation of AGEs causes non-enzymatic cross-linking in collagen type 1, [54] which leads to an increased bone stiffness and decreased plasticity and bone strength $[26,55,56]$. Furthermore, the accumulation of AGEs increased cortical porosity and decreased bone turnover [56-58], although the exact mechanism of lower bone turnover in T2DM is still unclear $[10,23]$.

\section{Sarcopenia and fall risk}

Sarcopenia is the age-related decline in skeletal muscle mass, quality and function [59].

Muscle mass can be determined by measuring appendicular lean mass (ALM) using DXA [60-62]. Muscle function consists of muscle strength and physical performance. Muscle strength is often measured by handgrip strength and physical performance by gait-speed [59].

Currently, there are different definitions for sarcopenia [59,63,64]. The most commonly used definitions are the European Working Group on Sarcopenia in Older People (EWGSOP) [59], The Foundation for the National Institutes of Health (FNIH) [64] and the International Working Group on Sarcopenia (IWGS) [63] (Table 1). Importantly, the cut-off points used by the EWGSOP, the FNIH and the IWGS differ and there is no consensus about what definition should be used $[59,65]$. Based on these definitions, the reported prevalences ranged between 1 and 29\% in aging adults [66]. The prevalence of sarcopenia increased with age, and was reported to be up to $40 \%$ in adults of 80 years and older [67]. Literature is inconsistent when comparing prevalence of sarcopenia in women and men. Most studies reported no association with gender [68-72], while others reported an increased prevalence in men [73] or in women [74].

The exact mechanism behind the development of sarcopenia is still unclear, but it is suggested to be a multifactorial process determined by different factors such as molecular and cellular changes, imbalance between protein synthesis and degradation, exercise, nutrition, chronic inflammation and oxidative stress [75-78].

During ageing loss and atrophy of muscle fibers occurs, especially of muscle fibers type II (fast muscle fibers) that are important for muscle function [79]. These muscle fibers type II are replaced by type I fibers (slow muscle fibers) [80], resulting in loss of muscle mass and a deterioration of muscle contractility [81]. In addition there is also a decrease of motor neurons which are important for balance [35].

Muscle contractility might also be negatively influenced by age related changes in structure of the contractile proteins myosin and actin that might be caused by the accumulation of reactive oxidative species (ROS) [81]. In addition, the amount of 'normally' structured myosin, wherein myosin heads are located in a strong-binding and force generating state, is decreased [82,83]. The amount of interaction between myosin and actin seems to decrease as well during aging, which partly contributes to the loss of contractibility [84].

In literature, sarcopenia is described as an important risk factor for falls, which increases fracture risk especially in elderly [85-87]. Hida 
Table 1

Most common definitions of sarcopenia; the definition, cut-off points and prevalences of sarcopenia in men and women.

\begin{tabular}{|c|c|c|c|c|c|c|}
\hline & \multirow[t]{2}{*}{ Definition } & \multirow[t]{2}{*}{ Cut-off points } & \multicolumn{4}{|l|}{ Prevalences } \\
\hline & & & Adults & Men & Women & T2DM \\
\hline \multirow[t]{6}{*}{ EWGSOP } & \multirow[t]{2}{*}{$\begin{array}{l}\text { ALM adjusted for height } \\
\text { square }\end{array}$} & \multirow[t]{2}{*}{$\begin{array}{l}<7,25 \mathrm{~kg} / \mathrm{m}^{2} \text { for men, }<5,67 \mathrm{~kg} / \mathrm{m}^{2} \\
\text { for women }\end{array}$} & $1-30 \%$ ( $\geq 50$ years) $[43]$ & $\begin{array}{l}6,8 \% \text { (mean age } 74 \\
\text { years) [46] }\end{array}$ & $\begin{array}{l}4,6 \% \text { (mean age } 74 \text { years) } \\
{[46]}\end{array}$ & \multirow[t]{6}{*}{ NA } \\
\hline & & & $\begin{array}{l}2,9 \% \text { (mean age } 74 \text { years, healthy } \\
\text { elderly) [44] }\end{array}$ & $\begin{array}{l}11,5 \% \text { ( } \geq 65 \text { years) } \\
{[45]}\end{array}$ & $16,3 \%$ ( $\geq 65$ year) $[45]$ & \\
\hline & \multirow[t]{2}{*}{ Handgrip strength } & \multirow[t]{2}{*}{$<30 \mathrm{~kg}$ for men, $<20 \mathrm{~kg}$ for women } & $12,5 \%$ (mean age 85 years) [42] & \multirow[t]{4}{*}{$\begin{array}{l}14,7 \% \text { (mean age } 74 \\
\text { years) [41] }\end{array}$} & \multirow[t]{4}{*}{$\begin{array}{l}20,2 \% \text { (mean age } 74 \\
\text { years) [41] }\end{array}$} & \\
\hline & & & $18 \%$ (mean age 74 years) $[41]$ & & & \\
\hline & Gait speed & $\leq 0,8 \mathrm{~m} / \mathrm{s}$ & $22,1 \%$ (mean age 82 years) [40] & & & \\
\hline & & & $\begin{array}{l}25,2 \% \text { (mean age } 80 \text { years healthy } \\
\text { elderly) [44] }\end{array}$ & & & \\
\hline \multirow[t]{2}{*}{ FNIH } & ALM adjusted for BMI & $<0,789$ for men, $<0,512$ for women & $\begin{array}{l}0,6 \% \text { (mean age } 74 \text { years, healthy } \\
\text { elderly) [44] }\end{array}$ & \multirow[t]{2}{*}{$\begin{array}{l}27,8 \% \text { ( } \geq 60 \text { years) } \\
{[47]}\end{array}$} & \multirow[t]{2}{*}{$19,3 \%$ ( $\geq 60$ years) $[47]$} & \multirow[t]{2}{*}{ NA } \\
\hline & Handgrip strength & $<26 \mathrm{~kg}$ for men, $<16 \mathrm{~kg}$ for women & $\begin{array}{l}4,1 \% \text { (mean age } 80 \text { years, geriatric } \\
\text { outpatients) [44] }\end{array}$ & & & \\
\hline \multirow[t]{2}{*}{ IWGS } & $\begin{array}{l}\text { ALM adjusted for height } \\
\text { square }\end{array}$ & $\begin{array}{l}<7,23 \mathrm{~kg} / \mathrm{m}^{2} \text { for men, }<5,67 \mathrm{~kg} / \mathrm{m}^{2} \\
\text { for women }\end{array}$ & $\begin{array}{l}0 \% \text { (mean age } 74 \text { years, healthy } \\
\text { elderly) [44] }\end{array}$ & \multirow[t]{2}{*}{ NA } & \multirow[t]{2}{*}{ NA } & \multirow[t]{2}{*}{ NA } \\
\hline & Gait speed & $\leq 1,0 \mathrm{~m} / \mathrm{s}$ & $\begin{array}{l}19,4 \% \text { (mean age } 82 \text { years) [40] } \\
21,1 \% \text { (mean age } 80 \text { years, geriatric } \\
\text { outpatient) [44] }\end{array}$ & & & \\
\hline
\end{tabular}

Abbreviations:

EWGSOP = European Working Group on Sarcopenia in Older People.

FNIH = Foundation for the National Institutes of Health.

IWGS = International Working Group on Sarcopenia.

$\mathrm{ALM}=$ Appendicular lean mass.

$\mathrm{BMI}=$ Body mass index

$\mathrm{NA}=$ Not available

et al. reported sarcopenia as an independent risk factor for hip fracture [88]. The 2-year fall incidence risk in subjects with sarcopenia was 1,6-3.2 times as high in participants with sarcopenia compared to those without sarcopenia $[89,90]$. Stability and balance are important to prevent falls, both are affected in patients with sarcopenia, which might explain the increased risk of falls [91]. In addition, muscle mass shock absorption capacity is reduced, leading to a higher impact on bone during a fall and an increased fracture risk [90,92].

Patients with sarcopenia often enter a vicious circle, wherein reduction of physical activity [59] and mobility [91] occurs, causing enhanced muscle loss, impaired balance and loss of mobility, resulting in impaired functional performance leading to an increased risk of falls and fractures [62,93].

\subsection{Sarcopenia and bone fragility}

According to literature, sarcopenia affects bone tissue and is associated with osteoporosis [94]. Therefore, sarcopenia is considered as a risk factor for development of osteoporosis, but osteoporosis might as well increase the risk of sarcopenia, and a vicious circle is created wherein both conditions may worsen each other [87,93,94].

Bone and muscle tissue can influence each other and because of the common pathophysiological pathways behind and risk factors for the development of sarcopenia and osteoporosis, some authors introduced the terminology "osteosarcopenia" [95].

Biochemically, osteocalcin, secreted solely by osteoblasts stimulates muscle tissue resulting in increased insulin sensitivity and myoblast proliferation $[96,97]$. Muscle tissue on the other hand might affect bone tissue by secreting different endocrine molecules; one of them being myostatin, which is expressed during bone regeneration [98]. A myostatin deficiency might result in an increase of bone mass [98-100].

Mechanistically, sarcopenia and osteoporosis have some similar risk factors, for example decreased physical activity, obesity, malnutrition, corticosteroids use, genetic polymorphisms, and some endocrine disorders such as T2DM [101,102]. Obesity is also a risk factor for both sarcopenia and osteoporosis. It is suggested that infiltration of fatty tissue in muscle- and bone tissue stimulates the development of osteosarcopenia $[95,103-106]$. Fat infiltration might not only be caused by ageing [95], but could also be the result of chronic inflammation which is perpetuated by obesity. Chronic inflammation causes secretion of cytokines by body fat and bone marrow and inhibition of myogenesis, osteoblast differentiation and production, which results in less healthy functional muscle and bone tissue [26,107-109].

\subsection{Sarcopenia and T2DM}

Little is known about the prevalence of sarcopenia in T2DM. Decreased muscle strength and function, handgrip strength and gait speed was reported in patients with T2DM compared to healthy controls $[110,111]$, but the prevalence of sarcopenia was not reported in these studies. In a cohort study, $15,7 \%$ of the patients with T2DM had sarcopenia compared to $6,9 \%$ of the healthy controls with an odds ratio (OR) for sarcopenia of 3.06, [1.42-6.62] after adjustment for multiple factors such as age, BMI and sex [33]. In this study however, sarcopenia was diagnosed based on a skeletal muscle index(SMI) measured by DXA, and was not based on one of the more current definitions, as described in Section 4 and Table 1 [33].

The mechanism leading to decreased muscle mass and function and/or sarcopenia in T2DM is yet unclear and the association between sarcopenia and fracture risk is not yet reported in patients with T2DM.

Insulin resistance causes loss of muscle tissue, which in turn decreases insulin sensitivity if the glucose supply remains constant, and thus may lead to a vicious circle and the unset of sarcopenia $[35,112,113]$. Insulin signalling can also be affected due to fat infiltration in muscle tissue [114], leading to increased insulin production and in later phase to a decrease of insulin sensitivity [115].

During ageing the function and the number of mitochondria decreases $[116,117]$. On top of this, due to T2DM, the functionality of the mitochondria decreases and the structure changes $[118,119]$. Metabolic inflexibility, the process wherein the numbers of functional 
mitochondria is decreased resulting in a competition between fatty acids and glucose to receive oxidative degradation [120], leads to increased ROS and oxidative stress thereby affecting insulin sensitivity negatively [121]. Therefore it is not yet clear whether mitochondrial dysfunction is a cause or a consequence of T2DM [122].

Patients with T2DM are known to be more often obese or overweight [40], are less active [123], more often have sedentary behavior [11], experience insulin resistance and oxidative stress due to the chronic inflammatory disease [93] and T2DM is often present in elderly [124]. All of these factors are known to be associated with sarcopenia in the general population and might explain the additional reduction in muscle mass and function in patients with T2DM [35,86,93,125]. However, patients with T2DM have different phenotypes and wellregulated T2DM might not be associated with a decrease in muscle mass. Hence loss of muscle mass and function and/or the development of sarcopenia will probably not occur in all patients with T2DM, but might depend on the presence of those risk factors. Further research is necessary to understand the mechanism behind the decrease in muscle mass and function in subtypes of T2DM patients.

\section{Fall risk and T2DM}

Patients with T2DM fall more frequently compared to subjects without diabetes $[126,127]$. Schwartz et al. reported an OR of 1,68 for the risk of falling more than once a year for older women with T2DM without insulin-use compared to healthy controls, and for insulin-users, the OR was 2,78 compared to healthy controls [126]. It is known, that a history of falls increases the risk of future falls, which leads to fear of falling [128] leading to a decrease in mobility, which increases the risk of falls even more [129]. Recurrent falls in patients with T2DM can be explained by different disease related factors, such as peripheral and autonomic neuropathy, retinopathy, microvascular complications of T2DM, unintended effects of anti-diabetic and other drugs, and comorbidities (e.g. obesity or sarcopenia) $[14,26,85-87,130]$, which are illustrated in Fig. 1.

Complications of T2DM, such as retinopathy (60\%) or neuropathy (30-50\%), increase the risk of falls [14,131-133]. Impaired vision can lead to loss of contrast sensitivity and depth perception, thereby increasing fall risk [134]. Neuropathy increases the risk of falls due to loss of sensitivity [131], which influences balance [132], walking stability [135] and ankle strength negatively [136]. Indeed, vibration perception was lower in a group of fallers compared to a group of non-fallers while no other differences were found considering fall-related risk factors in the falling and non-falling group [132]. In addition, about $15 \%$ of patients with T2DM will develop peripheral post-ganglionic autonomic neuropathy [137], which causes orthostatic hypotension and thus increases the risk of falling in T2DM [138,139].

Several anti-diabetic drugs, especially insulin therapy, can cause hypoglycaemia [140,141]. The fall risk in patients with T2DM who have cardiovascular co-morbidities, such as hypertension, is increased as treatment of hypertension can cause orthostatic hypotension and vertigo [142], and cardiac arrhythmias increase fall risk in elderly [143]. Additionally, an association between hypoglycaemia and cardiac arrhythmia was reported in patients with T2DM [143,144].

\section{Summary}

In summary, fracture risk in patients with T2DM is reported to be elevated although not in all studies and the mechanisms leading to fracture are multifactorial. In Fig. 2 we have illustrated the different factors that might contribute to fracture risk in patients with T2DM.

Although BMD measured by DXA is reported to be normal or even elevated in most studies, T2DM may lead to impaired bone quality due to decay of bone (micro)structure and bone material properties often in the context of decreased bone turnover, resulting in reduced bone strength. The combination of decreased bone strength and increased fall risk, related to T2DM specific risk factors, such as peripheral neuropathy, retinopathy, microvascular complications, obesity, co-morbidities and (diabetes) medication, may lead to an increased fracture risk in T2DM.

In addition, although literature is sparse, T2DM might also affect muscle tissue and due to various factors, such as sedentary behaviour, obesity and oxidative stress patients with T2DM develop sarcopenia more often compared to non-T2DM population. Sarcopenia contributes to the risk of falls and alters the fall mechanism thereby increasing fracture risk. In addition, sarcopenia and osteoporosis are related, sharing common pathophysiological pathways and risk factors.

We postulate, that the impairment of muscle and bone might be different according to the phenotype of T2DM patients and that patients at risk for development of bone fragility, sarcopenia, falls and thus fractures might be patients with a higher HbA1c, a longer diabetes duration, with a higher prevalence of diabetic complications and comorbidities, such as obesity and cardiovascular disease. A combined approach focussing on bone fragility, fall risk and the interplay with sarcopenia is of interest for future research regarding fracture risk in patients with T2DM.

\section{Contributors}

All authors were involved in drafting the article or revising it critically for important intellectual content, and all authors approved the final version.

\section{Conflict of interest}

The authors declare that they have no conflict of interest.

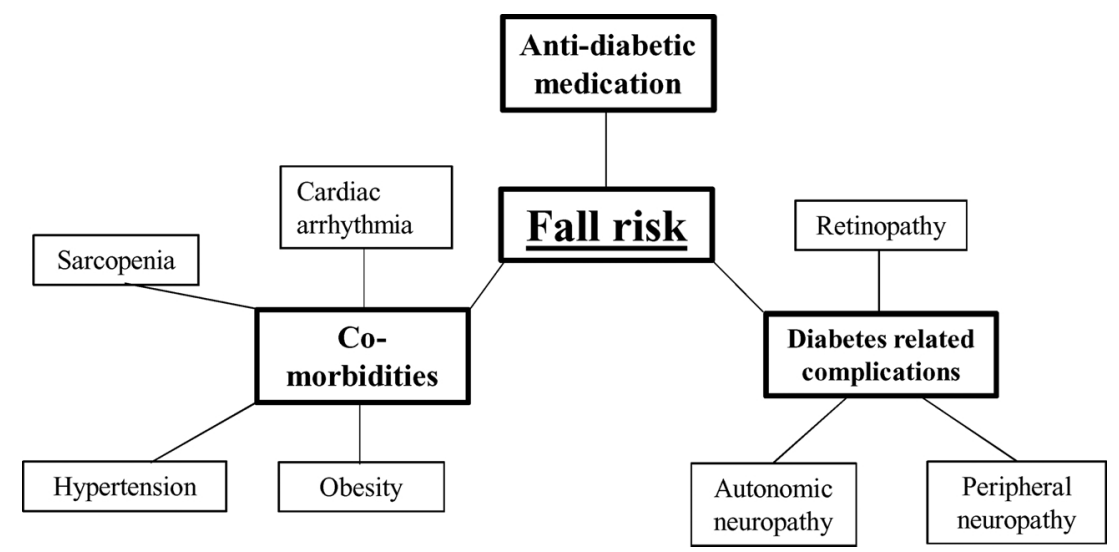

Fig. 1. Factors attributing to fall risk in T2DM. 


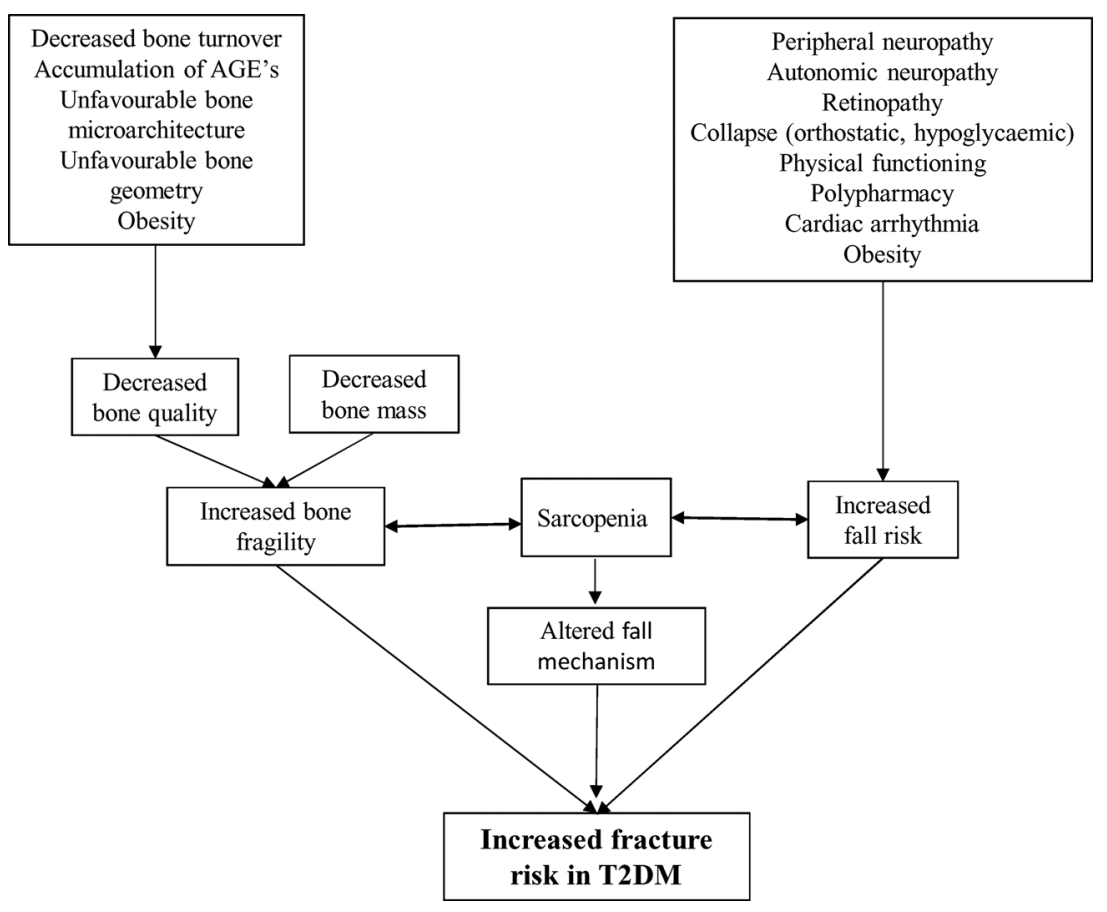

Fig. 2. Mechanisms of increased fracture risk in T2DM. Adapted with permission from de Waard et al. (2014) [47] T2DM: type 2 diabetes mellitus AGE's: advanced glycated end products.

\section{Funding}

This research did not receive any specific grant from funding agencies in the public, commercial, or not-for-profit sectors.

\section{Provenance and peer review}

This article has undergone peer review.

\section{References}

[1] https://www.diabetes.org.uk/resources-s3/2017-11/diabetes-key-statsguidelines-april2014.pdf (2017 Nov).

[2] D.R. Whiting, L. Guariguata, C. Weil, J. Shaw, IDF diabetes atlas: global estimates of the prevalence of diabetes for 2011 and 2030, Diabetes Res. Clin. Pract. 94 (3) (2011) 311-321.

[3] A. Kautzky Willer, J. Harreiter, G. Pacini, Sex and gender differences in risk, pathophysiology and complications of type 2 diabetes mellitus, Endocr. Rev. 37 (3) (2016) 278-316.

[4] B.K. Wich, M. Carnes, Menopause and the aging female reproductive system, Endocrinol. Metab. Clin. North Am. 24 (2) (1995) 273-295.

[5] M.C. Carr, J.D. Brunzell, Abdominal obesity and dyslipidemia in the metabolic syndrome: importance of type 2 diabetes and familial combined hyperlipidemia in coronary artery disease risk, J. Clin. Endocrinol. Metab. 89 (6) (2004) 2601-2607.

[6] C. Bogardus, S. Lillioja, D.M. Mott, C. Hollenbeck, G. Reaven, Relationship between degree of obesity and in vivo insulin action in man, Am. J. Physiol. 248 (3 Pt. (1)) (1985) E286-E291.

[7] R.A. Defronzo, Glucose intolerance and aging: evidence for tissue insensitivity to insulin, Diabetes 28 (12) (1979) 1095-1101.

[8] B.H. Goodpaster, F.L. Thaete, J.A. Simoneau, D.E. Kelley, Subcutaneous abdominal fat and thigh muscle composition predict insulin sensitivity independently of visceral fat, Diabetes 46 (10) (1997) 1579-1585.

[9] M. Manco, G. Nolfe, M. Calvani, A. Natali, J. Nolan, E. Ferrannini, G. Mingrone, Menopause, insulin resistance, and risk factors for cardiovascular disease, Menopause 13 (5) (2006) 809-817.

[10] E. Carnevale, Skeletal involvement in patients with diabetes mellitus, Diabetes Metab. Res. Rev. 20 (3) (2004) 196-204.

[11] S.A. Abdulameer, S.A. Sulaiman, M.A. Hassali, K. Subramaniam, M.N. Sahib, Osteoporosis and type 2 diabetes mellitus: what do we know, and what we can do? Patient Prefer Adherence 6 (2012) 435-448.

[12] M. Janghorbani, R.M. Van Dam, W.C. Willett, F.B. Hu, Systematic review of type 1 and type 2 diabetes mellitus and risk of fracture, Am. J. Epidemiol. 166 (5) (2007) 495-505.

[13] M. Yamamoto, T. Yamaguchi, M. Yamauchi, H. Kaji, T. Sugimoto, Diabetic patients have an increased risk of vertebral fractures independent of BMD or diabetic complications, J. Bone Miner. Res. 24 (4) (2009) 702-709.

[14] D.E. Bonds, J.C. Larson, A.V. Schwartz, E.S. Strotmeyer, J. Robbins, B.L. Rodriguez, K.C. Johnson, K.L. Margolis, Risk of fracture in women with type 2 diabetes: the Women's Health Initiative Observational Study, J. Clin. Endocrinol. Metab. 91 (9) (2006) 3404-3410.

[15] E.A.C. de Waard, A. Koster, T. Melai, T.A. van Geel, R.M.A. Henry, M.T. Schram, P.C. Dagnelie, C.J. van der Kallen, S.J.S. Sep, C.D.A. Stehouwer, N.C. Schaper, S. Kohler, H. Savelberg, P. Geusens, J.P.W. van den Bergh, The association between glucose metabolism status, diabetes severity and a history of fractures and recent falls in participants of 50 years and older-the Maastricht Study, Osteoporos. Int. 27 (11) (2016) 3207-3216.

[16] M. Rossini, S. Adami, F. Bertoldo, D. Diacinti, D. Gatti, S. Giannini, A. Giusti, N. Malavolta, S. Minisola, G. Osella, M. Pedrazzoni, L. Sinigaglia, O. Viapiana, G.C. Isaia, Guidelines for the diagnosis, prevention and management of osteoporosis, Reumatismo 68 (1) (2016) 1-39.

[17] J. Compston, A. Cooper, C. Cooper, N. Gittoes, C. Gregson, N. Harvey, S. Hope, J.A. Kanis, E.V. McCloskey, K.E.S. Poole, D.M. Reid, P. Selby, F. Thompson, A. Thurston, N. Vine, UK clinical guideline for the prevention and treatment of osteoporosis, Arch. Osteoporos. 12 (1) (2017) 43.

[18] Osteoporosis: Assessing the Risk of Fragility Fracture, Clinical Guideline, National Institute for Health and Care Excellence, 2012, https://www.nice.org.uk/ guidance/cg146.

[19] A.V. Schwartz, E. Vittinghoff, D.C. Bauer, T.A. Hillier, E.S. Strotmeyer, K.E. Ensrud, M.G. Donaldson, J.A. Cauley, T.B. Harris, A. Koster, C.R. Womack, L. Palermo, D.M. Black, Association of BMD and FRAX score with risk of fracture in older adults with type 2 diabetes, JAMA 305 (21) (2011) 2184-2192.

[20] V. Carnevale, S. Morano, A. Fontana, M.A. Annese, M. Fallarino, T. Filardi, M. Copetti, F. Pellegrini, E. Romagnoli, C. Eller Vainicher, V.V. Zhukouskaya, I. Chiodini, G. D'Amico, Assessment of fracture risk by the FRAX algorithm in men and women with and without type 2 diabetes mellitus: a cross-sectional study, Diabetes Metab. Res. Rev. 30 (4) (2014) 313-322.

[21] A.V. Schwartz, Epidemiology of fractures in type 2 diabetes, Bone 82 (2016) 2-8.

[22] A.D. Dede, S. Tournis, I. Dontas, G. Trovas, Type 2 diabetes mellitus and fracture risk, Metabolism 63 (12) (2014) 1480-1490.

[23] V. Carnevale, E. Romagnoli, L. D'Erasmo, E. D'Erasmo, Bone damage in type 2 diabetes mellitus, Nutr. Metab. Cardiovasc. Dis. 24 (11) (2014) 1151-1157.

[24] A.V. Schwartz, D.E. Sellmeyer, E.S. Strotmeyer, F.A. Tylavsky, K.R. Feingold, H.E. Resnick, R.I. Shorr, M.C. Nevitt, D.M. Black, J.A. Cauley, S.R. Cummings, T.B. Harris, Diabetes and bone loss at the hip in older black and white adults, J. Bone Miner. Res. 20 (4) (2005) 596-603.

[25] A.V. Schwartz, Diabetes mellitus does it affect bone? Calcif. Tissue Int. 73 (6) (2003) 515-519.

[26] J.S. Walsh, T. Vilaca, Obesity, type 2 diabetes and bone in adults, Calcif. Tissue Int. 100 (5) (2017) 528-535.

[27] W.D. Leslie, M.R. Rubin, A.V. Schwartz, J.A. Kanis, Type 2 diabetes and bone, J. Bone Miner. Res. 27 (11) (2012) 2231-2237.

[28] N. Napoli, M. Chandran, D.D. Pierroz, B. Abrahamsen, A.V. Schwartz, S.L. Ferrari, I.O.F. Bone, G. Diabetes Working, Mechanisms of diabetes mellitus-induced bone fragility, Nat. Rev. Endocrinol. 13 (4) (2017) 208-219.

[29] S.W. Park, B.H. Goodpaster, E.S. Strotmeyer, N. de Rekeneire, T.B. Harris, A.V. Schwartz, F.A. Tylavsky, A.B. Newman, Decreased muscle strength and quality in older adults with type 2 diabetes: the health, aging, and body composition study, Diabetes 55 (6) (2006) 1813-1818.

[30] S.W. Park, B.H. Goodpaster, E.S. Strotmeyer, L.H. Kuller, R. Broudeau, 
C. Kammerer, N. de Rekeneire, T.B. Harris, A.V. Schwartz, F.A. Tylavsky, Y.W. Cho, A.B. Newman, Accelerated loss of skeletal muscle strength in older adults with type 2 diabetes: the health, aging, and body composition study, Diabetes Care 30 (6) (2007) 1507-1512.

[31] T. Hida, H. Shimokata, Y. Sakai, S. Ito, Y. Matsui, M. Takemura, T. Kasai, N. Ishiguro, A. Harada, Sarcopenia and sarcopenic leg as potential risk factors for acute osteoporotic vertebral fractureamong older women, Eur. Spine J. 25 (11) (2016) 3424-3431.

[32] K. Sanada, M. Miyachi, M. Tanimoto, K. Yamamoto, H. Murakami, S. Okumura, Y. Gando, K. Suzuki, I. Tabata, M. Higuchi, A cross-sectional study of sarcopenia in Japanese men and women: reference values and association with cardiovascular risk factors, Eur. J. Appl. Physiol. 110 (1) (2010) 57-65.

[33] T.N. Kim, M.S. Park, S.J. Yang, H.J. Yoo, H.J. Kang, W. Song, J.A. Seo, S.G. Kim, N.H. Kim, S.H. Baik, D.S. Choi, K.M. Choi, Prevalence and determinant factors of sarcopenia in patients with type 2 diabetes: the Korean Sarcopenic Obesity Study (KSOS), Diabetes Care 33 (7) (2010) 1497-1499.

[34] M.E. Levine, E.M. Crimmins, The impact of insulin resistance and inflammation on the association between sarcopenic obesity and physical functioning, Obesity (Silver Spring) 20 (2012) 2101-2106.

[35] T. Cederholm, A.J. Cruz-Jentoft, S. Maggi, Sarcopenia and fragility fractures, Eur. J. Phys. Rehabil. Med. 49 (1) (2013) 111-117.

[36] S. Balducci, M. Sacchetti, G. Orlando, L. Salvi, L. Pugliese, G. Salerno, V. D'Errico, C. Iacobini, F.G. Conti, S. Zanuso, A. Nicolucci, G. Pugliese, Correlates of muscle strength in diabetes: the study on the assessment of determinants of muscle and bone strength abnormalities in diabetes (SAMBA), Nutr. Metab. Cardiovasc. Dis. 24 (1) (2014) 18-26.

[37] World Health Organization, WHO Criteria for Diagnosis of Osteoporosis, (2017) http://www.4bonehealth.org/education/world-health-organization-criteriadiagnosis-osteoporosis/.

[38] H. Dobnig, J.C. Piswanger Solkner, M. Roth, B. Obermayer Pietsch, A. Tiran, A. Strele, E. Maier, P. Maritschnegg, C. Sieberer, A. Fahrleitner Pammer, Type 2 diabetes mellitus in nursing home patients: effects on bone turnover, bone mass, and fracture risk, J. Clin. Endocrinol. Metab. 91 (9) (2006) 3355-3363.

[39] N. Napoli, E.S. Strotmeyer, K.E. Ensrud, D.E. Sellmeyer, D.C. Bauer, A.R. Hoffman, T.T. Dam, E. Barrett Connor, L. Palermo, E.S. Orwoll, S.R. Cummings, D.M. Black, A.V. Schwartz, Fracture risk in diabetic elderly men: the MrOS study, Diabetologia 57 (10) (2014) 2057-2065.

[40] Scottish Diabetes Survey Monitoring Group, Survey 2015, http://www. diabetesinscotland.org.uk/Publications/SDS2015.pdf.

[41] H.H. Bolotin, H. Sievanen, J.L. Grashuis, Patient-specific DXA bone mineral density inaccuracies: quantitative effects of nonuniform extraosseous fat distributions, J. Bone Miner. Res. 18 (6) (2003) 1020-1027.

[42] T.N. Hangartner, C.C. Johnston, Influence of fat on bone measurements with dualenergy absorptiometry, Bone Miner. 9 (1) (1990) 71-81.

[43] J.A. Kanis, O. Johnell, A. Oden, H. Johansson, E. McCloskey, FRAX and the assessment of fracture probability in men and women from the UK, Osteoporos. Int. 19 (4) (2008) 385-397.

[44] A.J. Burghardt, G.J. Kazakia, S. Majumdar, A local adaptive threshold strategy for high resolution peripheral quantitative computed tomography of trabecular bone, Ann. Biomed. Eng. 35 (10) (2007) 1678-1686.

[45] J.A. MacNeil, S.K. Boyd, Accuracy of high-resolution peripheral quantitative computed tomography for measurement of bone quality, Med. Eng. Phys. 29 (10) (2007) 1096-1105.

[46] J.A. Macneil, S.K. Boyd, Bone strength at the distal radius can be estimated from high-resolution peripheral quantitative computed tomography and the finite element method, Bone 42 (6) (2008) 1203-1213.

[47] E.A.C. de Waard, T.A. van Geel, H.H. Savelberg, A. Koster, P.P. Geusens, J.P. van den Bergh, Increased fracture risk in patients with type 2 diabetes mellitus: an overview of the underlying mechanisms and the usefulness of imaging modalities and fracture risk assessment tools, Maturitas 79 (3) (2014) 265-274.

[48] E.A.C. de Waard, J.H.M. Driessen, J.J.A. de Jong, T. van Geel, R.M.A. Henry, H.A.W. van Onzenoort, M.T. Schram, P.C. Dagnelie, C.J. van der Kallen, S.J.S. Sep, C.D.A. Stehouwer, N.C. Schaper, A. Koster, H. Savelberg, C. Neef, P. Geusens, F. de Vries, J.P.W. van den Bergh, The association between insulin use and volumetric bone mineral density, bone micro-architecture and bone strength of the distal radius in patients with type 2 diabetes - The Maastricht study, Bone 101 (2017) $156-161$.

[49] A.G. Nilsson, D. Sundh, L. Johansson, M. Nilsson, D. Mellstrom, R. Rudang, M. Zoulakis, M. Wallander, A. Darelid, M. Lorentzon, Type 2 diabetes mellitus is associated with better bone microarchitecture but lower bone material strength and poorer physical function in elderly women: a population-based study, J. Bone Miner. Res. 32 (5) (2017) 1062-1071.

[50] A.J. Burghardt, A.S. Issever, A.V. Schwartz, K.A. Davis, U. Masharani, S. Majumdar, T.M. Link, High-resolution peripheral quantitative computed tomographic imaging of cortical and trabecular bone microarchitecture in patients with type 2 diabetes mellitus, J. Clin. Endocrinol. Metab. 95 (11) (2010) 5045-5055.

[51] E.W. Yu, M.S. Putman, N. Derrico, G. Abrishamanian Garcia, J.S. Finkelstein, M.L. Bouxsein, Defects in cortical microarchitecture among African-American women with type 2 diabetes, Osteoporos. Int. 26 (2) (2015) 673-679.

[52] J.M. Patsch, A.J. Burghardt, S.P. Yap, T. Baum, A.V. Schwartz, G.B. Joseph, Increased cortical porosity in type 2 diabetic post-menopausal women with fragility fractures, J. Bone Miner. Res. 28 (2013) 313-324.

[53] R. Bucala, H. Vlassara, Advanced glycosylation end products in diabetic renal and vascular disease, Am. J. Kidney Dis. 26 (6) (1995) 875-888.

[54] M. Saito, K. Fujii, Y. Mori, K. Marumo, Role of collagen enzymatic and glycation induced cross-links as a determinant of bone quality in spontaneously diabetic WBN/Kob rats, Osteoporos. Int. 17 (10) (2006) 1514-1523.

[55] N.C. Avery, A.J. Bailey, The effects of the Maillard reaction on the physical properties and cell interactions of collagen, Pathol. Biol. (Paris) 54 (7) (2006) 387-395.

[56] D. Vashishth, G.J. Gibson, J.I. Khoury, M.B. Schaffler, J. Kimura, D.P. Fyhrie, Influence of nonenzymatic glycation on biomechanical properties of cortical bone, Bone 28 (2) (2001) 195-201.

[57] S.Y. Tang, D. Vashishth, The relative contributions of non-enzymatic glycation and cortical porosity on the fracture toughness of aging bone, J. Biomech. 44 (2) (2011) 330-336.

[58] U. Valcourt, B. Merle, E. Gineyts, S. Viguet-Carrin, P.D. Delmas, P. Garnero, Nonenzymatic glycation of bone collagen modifies osteoclastif activity and differentiation, J. Biol. Chem. 282 (8) (2007) 5691-5703.

[59] A.J. Cruz-Jentoft, J.P. Baeyens, J.M. Bauer, Y. Boirie, T. Cederholm, F. Landi, F.C. Martin, J.P. Michel, Y. Rolland, S.M. Schneider, E. Topinkova, M. Vandewoude, M. Zamboni, Sarcopenia: European consensus on definition and diagnosis: report of the European Working Group on sarcopenia in older people, Age Ageing 39 (4) (2010) 412-423.

[60] R.N. Baumgartner, D.L. Waters, D. Gallagher, J.E. Morley, P.J. Garry, Predictors of skeletal muscle mass in elderly men and women, Mech. Ageing Dev. 107 (2) (1999) 123-136.

[61] A.B. Newman, V. Kupelian, M. Visser, E. Simonsick, B. Goodpaster, M. Nevitt, S.B. Kritchevsky, F.A. Tylavsky, S.M. Rubin, T.B. Harris, Sarcopenia: alternative definitions and associations with lower extremity function, J. Am. Geriatr. Soc. 51 (11) (2003) 1602-1609.

[62] J.Z. Ilich, J.E. Inglis, O.J. Kelly, D.L. McGee, Osteosarcopenic obesity is associated with reduced handgrip strength, walking abilities, and balance in postmenopausal women, Osteoporos. Int. 26 (11) (2015) 2587-2595.

[63] R.A. Fielding, B. Vellas, W.J. Evans, S. Bhasin, J.E. Morley, A.B. Newman, G. Abellan van Kan, S. Andrieu, J. Bauer, D. Breuille, T. Cederholm, J. Chandler, C. De Meynard, L. Donini, T. Harris, A. Kannt, F. Keime Guibert, G. Onder, D. Papanicolaou, Y. Rolland, D. Rooks, C. Sieber, E. Souhami, S. Verlaan, M. Zamboni, Sarcopenia: an undiagnosed condition in older adults. Current consensus definition: prevalence, etiology, and consequences. International working group on sarcopenia, J. Am. Med. Dir. Assoc. 12 (4) (2011) 249-256.

[64] S.A. Studenski, K.W. Peters, D.E. Alley, P.M. Cawthon, R.R. McLean, T.B. Harris, L. Ferrucci, J.M. Guralnik, M.S. Fragala, A.M. Kenny, D.P. Kiel, S.B. Kritchevsky, M.D. Shardell, T.T. Dam, M.T. Vassileva, The FNIH sarcopenia project: rationale, study description, conference recommendations, and final estimates, J. Gerontol. A Biol. Sci. Med. Sci. 69 (5) (2014) 547-558.

[65] M.H. Edwards, E.M. Dennison, A. Aihie Sayer, R. Fielding, C. Cooper, Osteoporosis and sarcopenia in older age, Bone 80 (2015) 126-130.

[66] A.J. Cruz Jentoft, F. Landi, S.M. Schneider, C. Zuniga, H. Arai, Y. Boirie, L.K. Chen, R.A. Fielding, F.C. Martin, J.P. Michel, C. Sieber, J.R. Stout, S.A. Studenski, B. Vellas, J. Woo, M. Zamboni, T. Cederholm, Prevalence of and interventions for sarcopenia in ageing adults: a systematic review. Report of the International Sarcopenia Initiative (EWGSOP and IWGS), Age Ageing 43 (6) (2014) 748-759.

[67] R.N. Baumgartner, K.M. Koehler, D. Gallagher, L. Romero, S.B. Heymsfield, R.R. Ross, P.J. Garry, R.D. Lindeman, Epidemiology of sarcopenia among the elderly in New Mexico, Am. J. Epidemiol. 147 (8) (1998) 755-763.

[68] F. Landi, A.J. Cruz Jentoft, R. Liperoti, A. Russo, S. Giovannini, M. Tosato, E. Capoluongo, R. Bernabei, G. Onder, Sarcopenia and mortality risk in frail older persons aged 80 years and older: results from ilSIRENTE study, Age Ageing 42 (2) (2013) 203-209.

[69] F. Landi, R. Liperoti, A. Russo, S. Giovannini, M. Tosato, C. Barillaro, E. Capoluongo, R. Bernabei, G. Onder, Association of anorexia with sarcopenia in a community-dwelling elderly population: results from the ilSIRENTE study, Eur. J. Nutr. 52 (3) (2013) 1261-1268.

[70] D. Legrand, B. Vaes, C. Mathei, C. Swine, J.M. Degryse, The prevalence of sarco penia in very old individuals according to the European consensus definition: insights from the BELFRAIL study, Age Ageing 42 (6) (2013) 727-734.

[71] Y. Tanimoto, M. Watanabe, W. Sun, Y. Sugiura, Y. Tsuda, M. Kimura, I. Hayashida, T. Kusabiraki, K. Kono, Association between sarcopenia and higher-level functional capacity in daily living in community-dwelling elderly subjects in Japan, Arch. Gerontol. Geriatr. 55 (2) (2012) e9-13.

[72] L.P. Bastiaanse, T.I. Hilgenkamp, M.A. Echteld, H.M. Evenhuis, Prevalence and associated factors of sarcopenia in older adults with intellectual disabilities, Res. Dev. Disabil. 33 (6) (2012) 2004-2012.

[73] F. Landi, R. Liperoti, D. Fusco, S. Mastropaolo, D. Quattrociocchi, A. Proia A. Russo, R. Bernabei, G. Onder, Prevalence and risk factors of sarcopenia among nursing home older residents, J. Gerontol. A Biol. Sci. Med. Sci. 67 (1) (2012) $48-55$.

[74] H.P. Patel, H.E. Syddall, K. Jameson, S. Robinson, H. Denison, H.C. Roberts, M. Edwards, E. Dennison, C. Cooper, A. Aihie Sayer, Prevalence of sarcopenia in community-dwelling older people in the UK using the European Working Group on Sarcopenia in Older People (EWGSOP) definition: findings from the Hertfordshire Cohort Study (HCS), Age Ageing 42 (3) (2013) 378-384.

[75] I. Beyer, R. Njemini, I. Bautmans, C. Demanet, P. Beromann, T. Mets, Inflammation-related muscle weakness and fatigue in geriatric patients, Exp. Gerontol. 47 (1) (2012) 52-59.

[76] T.A. Churchward Venne, L. Breen, S.M. Phillips, Alterations in human muscle protein metabolism with aging: protein and exercise as countermeasures to offset sarcopenia, Biofactors 40 (2) (2014) 199-205.

[77] E. Marzetti, R. Calvani, M. Cesari, T.W. Buford, M. Lorenzi, B.J. Behnke, C. Leeuwenburgh, Mitochondrial dysfunction and sarcopenia of aging: from 
signaling pathways to clinical trials, Int. J. Biochem. Cell Biol. 45 (10) (2013) $2288-2301$.

[78] B.M. Scicchitano, L. Pelosi, G. Sica, A. Musaro, The physiopathologic role of oxidative stress in skeletal muscle, Mech. Ageing Dev. (2017) 17 (30058-1), S00476374 (17).

[79] L.V. Thompson, Effects of age and training on skeletal muscle physiology and performance, Phys. Ther. 74 (1) (1994) 71-81.

[80] M.A. Alnaqeeb, G. Goldspink, Changes in fibre type, number and diameter in developing and ageing skeletal muscle, J. Anat. 153 (1987) 31-45.

[81] L.V. Thompson, Age-related muscle dysfunction, Exp. Gerontol. 44 (1-2) (2009) 106-111.

[82] D.A. Lowe, J.T. Surek, D.D. Thomas, L.V. Thompson, Electron paramagnetic resonance reveals age-related myosin structural changes in rat skeletal muscle fibers, Am. J. Physiol. Cell Physiol. 280 (3) (2001) C540-C547.

[83] L.V. Thompson, D.A. Lowe, D.A. Ferrington, D.D. Thomas, Electron paramagnetic resonance: a high-resolution tool for muscle physiology, Exerc. Sport Sci. Rev. 29 (1) (2001) 3-6.

[84] D.A. Lowe, A.D. Husom, D.A. Ferrington, L.V. Thompson, Myofibrillar myosin ATPase activity in hindlimb muscles from young and aged rats, Mech. Ageing Dev. 125 (9) (2004) 619-627.

[85] M. Di Monaco, F. Vallero, R. Di Monaco, R. Tappero, Prevalence of sarcopenia and its association with osteoporosis in 313 older women following a hip fracture, Arch. Gerontol. Geriatr. 52 (1) (2011) 71-74.

[86] F. Hita-Contreras, A. Martinez-Amat, D. Cruz-Diaz, F.R. Perez-Lopez, Osteosarcopenic obesity and fall prevention strategies, Maturitas 80 (2) (2015) $126-132$.

[87] U. Tarantino, E. Piccirilli, M. Fantini, J. Baldi, E. Gasbarra, R. Bei, Sarcopenia and fragility fractures: molecular and clinical evidence of the bone-muscle interaction, J. Bone Joint Surg. Am. 97 (5) (2015) 429-437.

[88] T. Hida, N. Ishiguro, H. Shimokata, Y. Sakai, Y. Matsui, M. Takemura, Y. Terabe, A. Harada, High prevalence of sarcopenia and reduced leg muscle mass in Japanese patients immediately after a hip fracture, Geriatr. Gerontol. Int. 13 (2) (2013) 413-420.

[89] F. Landi, R. Liperoti, A. Russo, S. Giovannini, M. Tosato, E. Capoluongo, R. Bernabei, G. Onder, Sarcopenia as a risk factor for falls in elderly individuals: results from the ilSIRENTE study, Clin. Nutr. 31 (5) (2012) 652-658.

[90] D. Scott, M. Seibel, R. Cumming, V. Naganathan, F. Blyth, D.G. Le Couteur, D.J. Handelsman, L.M. Waite, V. Hirani, Sarcopenic obesity and its temporal associations with changes in bone mineral density, incident falls, and fractures in older men: the Concord health and ageing in men project, J. Bone Miner. Res. 32 (3) (2017) 575-583.

[91] D.L. Waters, L. Hale, A.M. Grant, P. Herbison, A. Goulding, Osteoporosis and gait and balance disturbances in older sarcopenic obese New Zealanders, Osteoporos. Int. 21 (2) (2010) 351-357.

[92] C.L. Himes, S.L. Reynolds, Effect of obesity on falls, injury, and disability, J. Am. Geriatr. Soc. 60 (1) (2012) 124-129.

[93] P. JafariNasabian, J.E. Inglis, O.J. Kelly, J.Z. Ilich, Osteosarcopenic obesity in women: impact, prevalence, and management challenges, Int. J. Womens Health 9 (9) (2017) 33-42.

[94] S. Sjöblom, J. Suuronen, T. Rikkonen, R. Honkanen, H. Kröger, J. Sirola, Relationship between postmenopausal osteoporosis and the components of clinical sarcopenia, Maturitas 75 (2) (2013) 175-180.

[95] H.P. Hirschfeld, R. Kinsella, G. Duque, Osteosarcopenia: where bone, muscle, and fat collide, Osteoporos. Int. 10 (2017) 2781-2790.

[96] P. Mera, K. Laue, M. Ferron, C. Confavreux, J. Wei, M. Galan Diez, A. Lacampagne, S.J. Mitchell, J.A. Mattison, Y. Chen, J. Bacchetta, P. Szulc, R.N. Kitsis, R. de Cabo, R.A. Friedman, C. Torsitano, T.E. McGraw, M. Puchowicz, I. Kurland, G. Karsenty, Osteocalcin signaling in myofibers is necessary and sufficient for optimum adaptation to exercise, Cell Metab. 25 (1) (2017) 218.

[97] C. Sassoli, A. Pini, F. Chellini, B. Mazzanti, S. Nistri, D. Nosi, R. Saccardi, F. Quercioli, S. Zecchi Orlandini, L. Formigli, Bone marrow mesenchymal stromal cells stimulate skeletal myoblast proliferation through the paracrine release of VEGF, PLoS One 7 (7) (2012) e37512.

[98] W. Guo, J. Flanagan, R. Jasuja, J. Kirkland, L. Jiang, S. Bhasin, The effects of myostatin on adipogenic differentiation of human bone marrow-derived mesenchymal stem cells are mediated through cross-communication between Smad3 and Wnt/beta-catenin signaling pathways, J. Biol. Chem. 283 (14) (2008) 9136-9145.

[99] C. Tagliaferri, Y. Wittrant, M.J. Davicco, S. Walrand, V. Coxam, Muscle and bone, two interconnected tissues, Ageing Res. Rev. 21 (2015) 55-70.

[100] H. Kaji, Interaction between muscle and bone, J. Bone Metab. 21 (1) (2014) $29-40$.

[101] D. Karasik, D.P. Kiel, Genetics of the musculoskeletal system: a pleiotropic approach, J. Bone Miner. Res. 23 (6) (2008) 788-802.

[102] N. Kawao, H. Kaji, Interactions between muscle tissues and bone metabolism, J. Cell. Biochem. 116 (5) (2015) 687-695.

[103] J.Z. Ilich, O.J. Kelly, J.E. Inglis, L.B. Panton, G. Duque, M.J. Ormsbee, Interrelationship among muscle, fat, and bone: connecting the dots on cellular, hormonal, and whole body levels, Ageing Res. Rev. 15 (2014) 51-60.

[104] S. Deshpande, A.W. James, J. Blough, A. Donneys, S.C. Wang, P.S. Cederna, S.R. Buchman, B. Levi, Reconciling the effects of inflammatory cytokines on mesenchymal cell osteogenic differentiation, J. Surg. Res. 185 (1) (2013) 278-285.

[105] J.M. Gimble, S. Zvonic, Z.E. Floyd, M. Kassem, M.E. Nuttall, Playin with bone and fat, J. Cell. Biochem. 98 (2) (2006) 251-266.

[106] C.J. Rosen, M.L. Bouxsein, Mechanisms of disease: is osteoporosis the obesity of bone? Nat. Clin. Pract. Rheumatol. 2 (1) (2006) 35-43.
[107] D. Maugeri, M.S. Russo, C. Franze, V. Motta, M. Motta, G. Destro, S. Speciale, A. Santangelo, P. Panebianco, M. Malaguarnera, Correlations between C-reactive protein, interleukin-6, tumor necrosis factor-alpha and body mass index during senile osteoporosis, Arch. Gerontol. Geriatr. 27 (2) (1998) 159-163.

[108] J.Z. Ilich, O.J. Kelly, Y. Kim, M.T. Spicer, Low-grade chronic inflammation perpetuated by modern diet as a promoter of obesity and osteoporosis, Arh. Hig. Rada Toksikol. 65 (2) (2014) 139-148.

[109] K.E. Wellen, G.S. Hotamisligil, Inflammation, stress, and diabetes, J. Clin. Invest. 115 (5) (2005) 1111-1119.

[110] N. Guerrero, D. Bunout, S. Hirsch, G. Barrera, L. Leiva, S. Henriquez, M.P. De la Maza, Premature loss of muscle mass and function in type 2 diabetes, Diabetes Res. Clin. Pract. 117 (2016) 32-38.

[111] J. Petrofsky, S. Lee, S. Bweir, Gait characteristics in people with type 2 diabetes mellitus, Eur. J. Appl. Physiol. 93 (5-6) (2005) 640-647.

[112] C. Guillet, Y. Boirie, Insulin resistance: a contributing factor to age-related muscle mass loss? Diabetes Metab. 31 (December (2)) (2005) 5S20-5S26.

[113] C.G. Lee, E.J. Boyko, E.S. Strotmeyer, C.E. Lewis, P.M. Cawthon, A.R. Hoffman, S.A. Everson-Rose, E. Barrett-Connor, E.S. Orwoll, Association between insulin resistance and lean mass loss and fat mass gain in older men without diabetes mellitus, J. Am. Geriatr. Soc. 59 (7) (2011) 1217-1224.

[114] C. Guillet, I. Delcourt, M. Rance, C. Giraudet, S. Walrand, M. Bedu, P. Duche, Y. Boirie, Changes in basal and insulin and amino acid response of whole body and skeletal muscle proteins in obese men, J. Clin. Endocrinol. Metab. 94 (8) (2009) 3044-3050.

[115] S. Kumar, S. O'Rahilly, Insulin Resistance: Insulin Action and Its Disturbances in Disease, (2005).

[116] A. Navarro, A. Boveris, The mitochondrial energy transduction system and the aging process, Am. J. Physiol. Cell Physiol. 292 (2) (2007) C670-C686.

[117] M.K. Shigenaga, T.M. Hagen, B.N. Ames, Oxidative damage and mitochondrial decay in aging, Proc. Natl. Acad. Sci. U. S. A. 91 (23) (1994) 10771-10778.

[118] D.E. Kelley, J. He, E.V. Menshikova, V.B. Ritov, Dysfunction of mitochondria in human skeletal muscle in type 2 diabetes, Diabetes 51 (10) (2002) 2944-2950.

[119] V.B. Ritov, E.V. Menshikova, J. He, R.E. Ferrell, B.H. Goodpaster, D.E. Kelley, Deficiency of subsarcolemmal mitochondria in obesity and type 2 diabetes, Diabetes 54 (1) (2005) 8-14.

[120] L. Storlien, N.D. Oakes, D.E. Kelley, Metabolic flexibility, Proc. Nutr. Soc. 63 (2) (2004) 363-368.

[121] M.K. Hesselink, V. Schrauwen Hinderling, P. Schrauwen, Skeletal muscle mitochondria as a target to prevent or treat type 2 diabetes mellitus, Nat. Rev. Endocrinol. 12 (11) (2016) 633-645.

[122] J.F. Dumas, G. Simard, M. Flamment, P.H. Ducluzeau, P. Ritz, Is skeletal muscle mitochondrial dysfunction a cause or an indirect consequence of insulin resistance in humans? Diabetes Metab. 35 (3) (2009) 159-167.

[123] E.H. Morrato, J.O. Hill, H.R. Wyatt, V. Ghushchyan, P.W. Sullivan, Physical ac tivity in U.S. adults with diabetes and at risk for developing diabetes, 2003, Diabetes Care 30 (2) (2007) 203-209.

[124] C.C. Cowie, K.F. Rust, D.D. Byrd Holt, M.S. Eberhardt, K.M. Flegal, M.M. Engelgau, S.H. Saydah, D.E. Williams, L.S. Geiss, E.W. Gregg, Prevalence of diabetes and impaired fasting glucose in adults in the U.S. population: National Health And Nutrition Examination Survey 1999-2002, Diabetes Care 29 (6) (2006) $1263-1268$.

[125] F.R. Perez-Lopez, I. Ara, Fragility fracture risk and skeletal muscle function, Climacteric 19 (1) (2016) 37-41.

[126] A.V. Schwartz, T.A. Hillier, D.E. Sellmeyer, H.E. Resnick, E. Gregg, K.E. Ensrud, P.J. Schreiner, K.L. Margolis, J.A. Cauley, M.C. Nevitt, D.M. Black, S.R. Cummings, Older women with diabetes have a higher risk of falls: a prospective study, Diabetes Care 25 (2002) 1749-1754.

[127] M.S. Maurer, J. Burcham, H. Cheng, Diabetes mellitus is associated with an increased risk of falls in elderly residents of a long-term care facility, J. Gerontol. Ser. A Biol. Sci. Med. Sci. 60 (9) (2005) 1157-1162.

[128] L.Z. Rubenstein, K.R. Josephson, Falls and their prevention in elderly people: what does the evidence show? Med. Clin. North Am. 90 (5) (2006) 807-824.

[129] S.M. Friedman, B. Munoz, S.K. West, G.S. Rubin, L.P. Fried, Falls and fear of falling: which comes first? A longitudinal prediciton model suggest strageties for primary and secondary prevention, J. Am. Geriatr. Soc. 50 (8) (2002) 1329-1335.

[130] E. Barrett-Connor, T.W. Weiss, C.A. McHorney, P.D. Miller, E.S. Siris, Predictors of falls among postmenopausal women: results from the National Osteoporosis Risk Assessment (NORA), Osteoporos. Int. 20 (5) (2009) 715-722.

[131] P. Hewston, N. Deshpande, Falls and balance impairments in older adults with type 2 diabetes: thinking beyond diabetic peripheral neuropathy, Can. J. Diabetes 40 (1) (2016) 6-9.

[132] S. Patel, S. Hyer, K. Tweed, S. Kerry, K. Allan, A. Rodin, J. Barron, Risk factors for fractures and falls in older women with type 2 diabetes mellitus, Calcif. Tissue Int. 82 (2) (2008) 87-91.

[133] S. Kurra, E. Siris, Diabetes and bone health: the relationship between diabetes and osteoporosis-associated fractures, Diabetes Metab. Res. Rev. 27 (5) (2011) 430-435.

[134] R.Q. Ivers, R.G. Cumming, P. Mitchell, K. Attebo, Visual impairment and falls in older adults: the Blue Mountains Eye Study, J. Am. Geriatr. Soc. 46 (1) (1998) 58-64.

[135] C. Wallace, G.E. Reiber, J. LeMaster, D.G. Smith, K. Sullivan, S. Hayes, C. Vath, Incidence of falls, risk factors for falls, and fall-related fractures in individuals with diabetes and a prior foot ulcer, Diabetes Care 25 (11) (2002) 1983-1986.

[136] H.B. Menz, S.R. Lord, R. St George, R.C. Fitzpatrick, Walking stability and sensorimotor function in older people with diabetic peripheral neuropathy, Arch. Phys. Med. Rehabil. 85 (2) (2004) 245-252. 
[137] P.A. Low, L.M. Benrud Larson, D.M. Sletten, T.L. Opfer Gehrking, S.D. Weigand, P.C. O'Brien, G.A. Suarez, P.J. Dyck, Autonomic symptoms and diabetic neuropathy: a population-based study, Diabetes Care 27 (12) (2004) 2942-2947.

[138] D. Mayne, N.R. Stout, T.J. Aspray, Diabetes, falls and fractures, Age Ageing 39 (5) (2010) 522-525.

[139] A.I. Vinik, D. Ziegler, Diabetic cardiovascular autonomic neuropathy, Circulation 115 (3) (2007) 387-397.

[140] L.M. Tilling, K. Darawil, M. Britton, Falls as a complication of diabetes mellitus in older people, J. Diabetes Complications 20 (3) (2006) 158-162.

[141] L.C. Hofbauer, C.C. Brueck, S.K. Singh, H. Dobnig, Osteoporosis in patients with diabetes mellitus, J. Bone Miner. Res. 22 (9) (2007) 1317-1328.
[142] S. Takaoka, T. Yamaguchi, K. Tanaka, M. Morita, M. Yamamoto, M. Yamauchi, S. Yano, T. Sugimoto, Fracture risk is increased by the complication of hypertension and treatment with calcium channel blockers in postmenopausal women with type 2 diabetes, J. Bone Miner. Metab. 31 (1) (2013) 102-107.

[143] U.H. Malabu, V.N. Vangaveti, R.L. Kennedy, Disease burden evaluation of fallrelated events in the elderly due to hypoglycemia and other diabetic complications: a clinical review, Clin. Epidemiol. 6 (2014) 287-294.

[144] J. Foster, P.A. Baillie, W.D. Strain, Hypoglycemia precipitating prolonged QT interval and myocardial ischemia in a patient with coronary heart disease and renal failure, Diabetic Hypoglycemia 4 (3) (2012) 9-11. 